\title{
項目反応間の局所依存性が項目母数の推定に与える影響 ——項目母数の比較可能性を確保した上での検討
}

\author{
登 藤 直 弥
}

The Effect of Local Dependence on Item Parameter Estimation

— A Comparison Based on Comparable Item Parameters_—

\author{
Naoya Todo
}

In this study, we assessed the effect of local dependence on item parameter estimation based on comparable item parameters, using Markov Chain Monte Carlo method. The results showed that if we estimate item parameters ignoring local dependence, item parameter estimation will be more inaccurate than taking local dependence into account. Furthermore, it was supposed that the result of previous works, which were not based on comparable item parameters, was distorted.

Key words: item response theory, local independence, local dependence, markov chain monte carlo

キーワード：項目反応理論, 局所独立性, 局所依存性, マルコフ連鎖モンテカルロ法

\section{1. 問 題と目的}

近年，日本においてもその利用が増加している項目 反応理論 (item response theory, IRT) は, テスト の作成・実施・評価に資する様々な利点を有したテス 卜理論である，項目反応理論に基づき作成されたテス トでは，テスト情報関数と呼ばれる特性值の関数を用 いることにより，推定される特性值の推定精度をその 水準ごとに評価することができる，また，等化と呼ば れる手続きを行うことにより，異なるテストを異なる 集団に対して実施した場合にも，得られた特性值の推 定值を共通の尺度上で評価することができるようにな る。さらには，テストの実施前にその得点分布を予測 することも可能になる.

この項目反応理論における重要な仮定に, 局所独立 性 (local independence) の仮定と呼ばれるものがある

東京大学大学院教育学研究科 ·日本学術振興会

(Graduate School of Education, The University of Tokyo/Japan Society for the Promotion of Science)

連絡先：干 113-0033 東京都文京区本郷 7-3-1

Tel : 090-5229-5738

E-mail : toudou@p.u-tokyo.ac.jp
(Lord \& Novick, 1968). 局所独立性の仮定とは,「特 性值 $\theta$ を固定したときに, 各項目への項目反応が統計 的に互いに独立である」という仮定のことである。す なわち, 項目 $j(1, \cdots, j, \cdots J)$ への反応 $u_{j}$ を, 正答 なら 1 , 誤答なら 0 とするとき, $J$ 個の項目への反応 が特定の正誤パタン $\left(u_{1}, u_{2}, \cdots, u_{J}\right)$ となる条件付同 時確率 $P\left(u_{1}, u_{2}, \cdots, u_{J} \mid \theta\right)$ が

$$
P\left(u_{1}, u_{2}, \cdots, u_{J} \mid \theta\right)=P\left(u_{1} \mid \theta\right) P\left(u_{2} \mid \theta\right) \cdots P\left(u_{J} \mid \theta\right)
$$

のように，各項目に関する条件付確率の積に等しくな るというのが，局所独立性の仮定である．この仮定は， 特性值 $\theta$ における項目 $j$ への正答確率を表す項目特性 関数を $P_{j}(\theta)$ とすると,

$$
P\left(u_{1}, u_{2}, \cdots, u_{J} \mid \theta\right)=\prod_{j=1}^{J} P_{j}(\theta)^{u_{j}}\left[1-P_{j}(\theta)\right]^{\left(1-u_{j}\right)}
$$

と表現することができる1).

局所独立性が満たされない状況は一般に局所依存性

1) Lord (1980) が指摘している様に, 項目特性関数は, 厳密に言えば,「特定の個人が特定の項目に正答する 確率」ではない. 本論文では, そのことをふまえた上 
(local dependence) と呼ばれるが, 先行研究では, 局所 依存性を引き起こすものとして様々な要因が挙げられ ている (Ferrara, Huynh, \& Michaels, 1999; Hoskens \& De Boeck, 1997; Kreiner \& Christensen, 2004; Yen, 1993). これらの要因は大きく以下の 3 つの夕イ プに分けることができる.

タイプI. 項目間に直接的なつながりのある項目群 タイプ II. 項目間に間接的なつながりのある項目群 タイプ III. 正答確率に特性值 $\theta$ 以外の特性が反映さ れている項目群

タイプIには, 前の項目への正答が当該項目での正 答の必要条件となるような項目群が含まれる。例えば, 1 問目である計算問題の結果を答えさせ 2 問目でその 計算過程を説明させる項目群や, 1 問目で $x=1,2,3,4$ のそれぞれの場合について $y=2 x+1$ の $y$ を求めさ せ, 2 問目で $x$ と $y$ の散布図を描かせる項目群などが これにあたる。

タイプIIには, 文章読解や図表の読み取りなどに関 する大問形式の項目群が含まれる。これらの項目群で は，特性值の水準が同じ受験者であっても，たまたま文 章の主旨を誤解したり, 図表を読み違えたりすると, そ の大問の多くの項目に䛊答する可能性が高くなるため, 大問内の項目間に相関が生じることになる。また，文 章読解問題の文章が，以前に読んだことのある文章で あったり, 強い興味をもっているテーマの文章であっ たりすると, 特性值の水準が同じ他の受験者よりもそ の大問の多くの項目に正答する可能性が高くなるため, このような受験者と大問の内容との交互作用の存在も, 大問内の項目間の相関に寄与し, 局所依存性を生じさ せることになる。

タイプIII には, 当該項目に正答する確率が研究者・ 分析者が想定している特性 $\theta$ に加え想定外の特性 $\theta^{\prime}$ に よっても規定されているような項目群が含まれる。こ のような項目群の例としては, 特異項目機能 (differential item functioning, DIF) が生じている項目群等が 挙げられる。タイプIII に含まれる項目群においては, それらに正答する確率が例えば受験者の性別といった 他の特性 $\theta^{\prime}$ によっても規定されている。したがって, 特性 $\theta$ で条件付けた場合でも, 他の特性 $\theta^{\prime}$ の個人差に よって項目間に相関が生じ, 局所依存性を生むことと

で,「受験者 $i$ が項目 $j$ に正答する確率」という慣例 的な表現を用いることとする。 なお，Lord の指摘と 局所独立性の概念の関倸については, 南風原 $(2000)$ が詳細に論じている.
なる。

池田 (1992) や石塚・中站・内田・前川 (2001)にお いて述べられているように, 日本の学力試験の特徵と して, 大問形式の出題が多いことが挙げられる。先述 の通り, 近年では日本に扔いても項目反応理論の利用 が増加していることと考え合わせると, 今後日本にお いて大問形式の問題を含むテストの作成 ·分析 ·評価 を行うにあたり, 項目反応理論の利用が増加していく ことが予想される。しかしながら, 大問形式の問題は 上述のタイプIIに含まれる項目群に該当し, これらの 問題に扔いては項目反応間に局所独立性が成り立たな いと考えられる. 先行研究においては, このような局 所依存性が疑われる項目反応デー夕に対して局所独立 性を仮定して分析を行った場合の影響について様々な 観点から検討がなされている（石塚他，2001; Junker， 1991; Lee, 2000; Sireci, Thissen, \& Wainer, 1991; 登藤, 2010, 2012).

例えば, Bradlow, Wainer, \& Wang (1999) や Chen \&Wang (2007) では, 局所依存性を考慮せずに分析を 行った場合に項目母数の推定值にバイアスが生じ, そ の標準誤差も増加することが報告されている。これら の研究においては, 局所依存性を表現する真のモデルと して Bayesian testlet model (BTM) (Wainer, Bradlow, \& Wang, 2007) や constant interaction model (Hoskens \& De Boeck, 1997) が使用されているが, これらのモデルにおいては特性值 $\theta$ における項目 $j$ へ の正答確率 $P_{j}(\theta)$ が通常項目反応理論の応用場面で使 用されるラッシュモデルや 2 パラメタ・ロジスティッ クモデル (2PLM) などと等しくならない (Braeken, 2011; Braeken, Tuerlinckx, \& De Boeck, 2007; Ip, 2010; Ip, Smith, \& De Boeck, 2009). つまり, 上記 の研究から得られた知見には, 本来比較不可能なもの を比較したことによる影響も含まれており, 先行研究 において局所依存性が項目母数の推定に与える直接的 な影響が検討されてきたとは言い難い.

これに関連して, 2010 年の Applied Psychological Measurement 誌では, BTM の項目母数を通常の項目 反応モデル (2PLM 等)に扔ける項目母数と比較可能 なものに変換するための方法が Ip, E.H. により提案さ れている. 先述の通り, 今後大問形式の問題を含むテ ストの分析等に際し項目反応理論を用いる機会が増加 するであろうことを考慮すると, 項目反応間の局所依 存性が項目母数の推定にどの様な影響を与えるのかを, 項目母数の比較可能性を確保した上で検討することは 
重要であると考えられる.

そこで, 本研究では, Ip (2010) の知見を援用し, 項 目母数の比較可能性を確保した上で, 項目反応間の局所 依存性が項目母数の推定にどの様な影響を与えるのか, シミュレーション実験を通して探索的な検討を行った.

\section{2. 方法 ${ }^{2)}$}

本研究では，大問形式の問題を含むテストに対する 仮想的な項目反応データを発生させ，これに対し局所 独立性を仮定する通常のモデルと局所依存性を考慮し た真のモデルを当てはめ, マルコフ連鎖モンテカルロ 法 (Markov Chain Monte Carlo, MCMC) により項 目母数の推定を行った. この手続きを複数回繰り返し, 得られた複数組の項目母数の推定值, ならびに, 項目母 数の真值を互いに比較可能な值に変換にした上で，項 目母数の推定量のバイアス (Bias), 平均二乗誤差平 方根 $(R M S E)$, 項目母数の真值と推定量との相関係数 (cor) を算出し, 局所依存性が項目母数の推定に与え る直接的な影響について検討を行った。

\section{1. 仮想的なデータの発生モデル}

大問形式の問題を含むテストに対する仮想的な項目反 応デー夕を発生させる際には, Bradlow, et al. (1999) で提案された以下の 2 值型の BTM,

$$
P_{j}\left(\theta_{i}\right)=\frac{1}{1+\exp \left(-1.7 \alpha_{j}\left(\theta_{i}-\beta_{j}-\gamma_{i d(j)}\right)\right)}
$$

を使用した。ここで， $\alpha_{j}$ ならびに $\beta_{j}$ はそれぞれ項目 $j$ の識別力と困難度に関する項目母数である. そして, $\gamma_{i d(j)}$ は項目 $j$ が含まれる大問 $d(j)$ における項目反応 間の局所依存性を表すために導入された受験者 $i$ に関 する受験者母数であり, 受験者 $i$ と大問 $d(j)$ の交互作 用を表している。よって, 2 值型の BTM においては受 験者 $i$ に関する受験者母数が $\theta_{i}-\gamma_{i d(j)}$ の形で表され ることになるため, $\gamma_{i d(j)}$ の值が正である場合には, 項 目 $j$ における受験者 $i$ の特性值は減少することとなり, $\gamma_{i d(j)}$ の值が負である場合には, 増加することとなる. また, $P_{j}\left(\theta_{i}\right)$ は特性值が $\theta_{i}$ で, かつ, 大問 $d(j)$ との 交互作用が $\gamma_{i d(j)}$ である受験者 $i$ が項目 $j$ に正答する 確率を表している。(3) 式からも明らかなように, 2 值 型のBTM においては特性值 $\theta$ で条件づけた場合にも

2) 本研究のシミュレーションは, 登藤 (2012) の手続き を一部変更したものである.
各項目への反応確率が $\theta$ 以外の受験者母数に依存する ため，このモデルに基づき発生させた項目反応データ において局所独立性は満たされなくなる。なお, BTM においては $\gamma_{i d(j)}$ の事前分布として,

$$
\gamma_{i d(j)} \sim N\left(0, \sigma_{\gamma_{d(j)}}^{2}\right)
$$

が仮定される。ここで， $\sigma_{\gamma_{d(j)}}^{2}$ は大問 $d(j)$ における局 所依存性の程度を示す母数となっており, この母数の 值が大きいほど大問 $d(j)$ における局所依存性の程度が

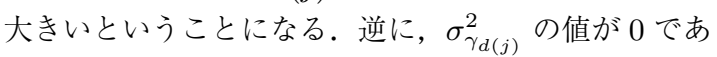
る場合には, 大問 $d(j)$ 内の全ての項目への反応が局所 独立となる。

\section{2. 分析モデル}

仮想的な項目反応データに当てはめる局所独立性を仮 定した通常の項目反応モデルとしては, 以下の $2 \mathrm{PLM}$,

$$
P_{j}^{* *}\left(\theta_{i}\right)=\frac{1}{1+\exp \left(-1.7 \alpha_{j}^{* *}\left(\theta_{i}-\beta_{j}^{* *}\right)\right)}
$$

を使用することとした。ここで， $P_{j}^{* *}\left(\theta_{i}\right)$ は特性值が $\theta_{i}$ である受験者 $i$ が項目 $j$ に正答する確率を表してお り, $\alpha_{j}^{* *}$ ならびに $\beta_{j}^{* *}$ はそれぞれ項目 $j$ の識別力と困 難度を表す項目母数である.

また，局所依存性を考慮した項目反応モデルとして は，仮想的な項目反応データを発生させる際に使用し た 2 值型の BTM を使用した。

\section{3. 項目母数の変換方法}

上述の (5) 式における $\alpha_{j}^{* *}$ は, $\theta_{i}=\beta_{j}^{* *}$ における項 目特性関数 $P_{j}^{* *}\left(\theta_{i}\right)$ の傾きを表す母数となっている. 一方，(3) 式における $\alpha_{j}$ は， $\gamma_{i d(j)}=0$ であるときの $\theta_{i}=\beta_{j}$ における項目特性関数 $P_{j}\left(\theta_{i}\right)$ の傾きを表して いる. したがって，(3) 式中の $\alpha_{j}$ と (5) 式中の $\alpha_{j}^{* *}$ で はその意味するところが互いに異なっており，これら の母数は互いに比較可能な状態とはなっていない. Ip (2010) は， $\alpha_{j}$ と $\alpha_{j}^{* *}$ が比較可能なものとなるために は (5) 式を $\gamma_{i d(j)}$ について周辺化すればよいと考え, 周 辺化テストレット項目反応関数 (marginalized testlet item response function, MIRF) と呼ばれる $\gamma_{i d(j)}$ を 積分消去した 2 值型の BTM を導出した（詳細につい ては Ip (2010) を参照のこと). その結果, (3) 式中の $\alpha_{j}$ を,

$$
\alpha_{j}^{*}=\tau \alpha_{j}
$$

のように変換すれば， $\alpha_{j}$ と $\alpha_{j}^{* *}$ が比較可能となるこ 
とを示した。ただし，

$$
\begin{gathered}
\tau=\frac{1}{\sqrt{k^{2}\left(1.7 \alpha_{j}\right)^{2} \sigma_{\gamma_{d(j)}}^{2}+1}} \\
k=\frac{16 \sqrt{3}}{15 \pi}
\end{gathered}
$$

である。また， $\beta_{j}^{* *} に$ 関しては変換を行わなくても比 較可能なこと,つまり, 2 PLM と比較可能な困難度母 数 $\beta_{j}^{*}$ が

$$
\beta_{j}^{*}=\beta_{j}^{* *}
$$

であることが同論文にて示されている.

本研究では, 項目母数の比較可能性を確保した上で 局所依存性の影響を検討するため, Ip (2010) で提案 された方法を使用し，2 值型の BTM に扔ける項目母 数を $2 \mathrm{PLM}$ の項目母数と比較可能な值に変換すること とした.

\section{4. シミュレーションの手続き}

シミュレーションを行う際には，全ての条件におい て, 大問形式の問題を含む仮想的なテストが 4 つの大 問から構成されるテストであるとし, 各大問は 5 項目 から成るものとした。また，各大問内で局所依存関係 にある項目の割合を要因として操作することとし，大 問内で局所依存関係にある項目を, 5 項目, 3 項目, 2 項 目と変化させ，局所依存性の影響に関する検討を行っ た。さらに，テストに含まれる 4 つの大問の局所依存 性の程度に関しても要因として操作することとし，テ ストに含まれる 4 つの大問の局所依存度について,

・ 4 つとも局所依存度が強い

・ 4 つのうち 3 つの局所依存度が強い

・4つのうち 2 つの局所依存度が強い

・4つのうち 1 つだけ局所依存度が強い

• 4 つとも局所依存度が弱い

という 5 つの条件を設定して, 局所依存性の影響に関 する検討を行った。ここで，大問の局所依存度の強弱 に関しては，2 值型の BTM を提案した Bradlow, et al. (1999) を引用している 95 件の論文のうち， 2 值 型の BTM を実際の大問形式の問題に対し適用した 2 件の論文 (Li, Bolt, \& Fu, 2005, 2006) と Bradlow, et al. (1999) を参考に決定した。具体的には，上記 の論文において推定された 17 個の $\sigma_{\gamma_{d(j)}}^{2}$ のうち上位 4 個の平均（1.4075）を局所依存度が強い大問におけ る $\sigma_{\gamma_{d(j)}}^{2}$ の值, 下位 4 個の平均 $(0.155)$ を局所依存
度が弱い大問における $\sigma_{\gamma_{d(j)}}^{2}$ の值とし, この基準に従 い仮想的な項目反応デー夕を発生させた，局所依存性 が項目母数の推定精度に与える影響について検討した Chen \& Wang (2007) では局所依存関係にある項目の 割合が要因として操作され, Bradlow, et al. (1999) においては大問の局所依存度が要因として操作されて いる．上記のようにシミュレーション計画を設定する ことで, これらの研究で見られた各要因の影響が, 項目 母数の比較可能性を考慮した上でも見られるのか, 検 討することが可能となる. 同時に, 本シミュレーショ ンでは受験者数についても要因として操作することと し, 受験者数を 1000 人, 300 人と変化させ, 局所依存 性の影響を検討することとした. 上記 2 つの先行研究 においては, 一貫して受験者数が 1000 人と固定され 検討が行われてきた。 そこで, 上記のように受験者数 を変化させることで, 受験者数が比較的多い場合のみ ならず少ない場合に関しても, 局所依存性の影響を検 討することが可能になる.

本研究で行ったシミュレーションの手順は以下の様 にまとめられる。

Step1, 各受験者の特性值 $\theta_{i}$, 各項目の項目母数 $\alpha_{j}$, $\beta_{j}$, ならびに, 各大問における項目反応間の局所 依存性を表現するための受験者母数 $\gamma_{i d(j)}(d(j)=$ $1,2,3,4)$ を，それぞれ標準正規分布 $N(0,1)$, 一様 分布 $U(0.5,1.5)$, 標準正規分布 $N(0,1)$, 正規分布 $N\left(0, \sigma_{\gamma_{d(j)}}^{2}\right)$ から発生させる.

Step2, 各受験者の各項目に対する正答確率を Step1 で得られた母数と 2 值型の BTM から計算し, $1000 \times$ $20(300 \times 20)$ の正答確率行列 $\mathbf{A}$ を作成する.

Step3, 一様分布 $U(0,1)$ から一様乱数を 20000 （6000）個発生させ， $1000 \times 20(300 \times 20 ）$ の一 様乱数行列 $\mathbf{B}$ を作成する.

Step4, 行列 A, B の各要素を比較し, 大問形式の問 題を含むテストに対する項目反応データの行列 Uを 作成する。具体的には, $\mathbf{A} の(i, j)$ 要素 $a_{i j}$ が $\mathbf{B}$ の $(i, j)$ 要素 $b_{i j}$ 以上であれば $\mathbf{U} の(i, j)$ 要素 $u_{i j}$ を 1 とし, $a_{i j}$ が $b_{i j}$ 未満であれば $u_{i j}$ を 0 とする(ここ で, $u_{i j}=1$ は受験者 $i$ が項目 $j$ に正答することを, $u_{i j}=0$ は項目 $j$ に䛊答することを，それぞれ表す).

Step5, Step4で得られた項目反応データに対して 2.1 節および 2.2 節で紹介した 2 つの分析モデルを当て はめ, 母数を推定する.

Step6, Step3〜 5の手順を $R$ 回繰り返す. 
Step7，2.3 節で解説した Ip (2010) の方法を利用し, 2 值型の BTM を当てはめた場合に得られる項目母 数の推定值とその真值を $2 \mathrm{PLM}$ の項目母数と比較可 能な值に変換する。

Step8, Step7 の結果得られた $R$ 組の推定値を用い, 2 つの分析モデルにおいて以下の指標值を計算する.

$$
\begin{gathered}
\operatorname{Bias}\left(\hat{\lambda}_{j}\right)=\frac{1}{R} \sum_{r=1}^{R} \hat{\lambda}_{j r}-\lambda_{j} \\
\operatorname{RMSE}\left(\hat{\lambda}_{j}\right)=\sqrt{\frac{1}{R} \sum_{r=1}^{R}\left(\hat{\lambda}_{j r}-\lambda_{j}\right)^{2}} \\
\operatorname{cor}(\hat{\boldsymbol{\lambda}}, \boldsymbol{\lambda})=\frac{1}{R} \sum_{r=1}^{R} \operatorname{cor}\left(\hat{\boldsymbol{\lambda}}_{r}, \boldsymbol{\lambda}\right)
\end{gathered}
$$

Step9, Step8 で得られる全 20 項目分の $\operatorname{Bias}\left(\hat{\lambda}_{j}\right)$ と $R M S E\left(\hat{\lambda}_{j}\right)$ のうち, 局所依存関係にある項目に対す る $\operatorname{Bias}\left(\hat{\lambda}_{j}\right)$ と $\operatorname{RMSE}\left(\hat{\lambda}_{j}\right)$ の值をそれぞれ平均し, $\operatorname{MBias}\left(\hat{\lambda}_{j}\right), \operatorname{MRMSE}\left(\hat{\lambda}_{j}\right)$ とする.

ここで, $\lambda_{j}$ は項目 $j$ に関する項目母数の真値を, $\hat{\lambda}_{j}$ は $\lambda_{j}$ の推定量を, $\hat{\lambda}_{j r}$ はそれらの $r$ 回目の推定値を, そ れぞれ表わしている。また，入は全 20 項目のうち局 所依存関係にある項目の $\alpha_{j}^{*}$ あるいは $\beta_{j}^{*}$ をの要素と

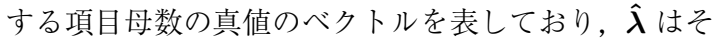
の推定量を, $\hat{\boldsymbol{\lambda}}_{r}$ はその $r$ 回目の推定値をそれぞれ表わ している.

$\operatorname{Bias}\left(\hat{\lambda}_{j}\right)$ は $\hat{\lambda}_{j}$ にどの程度の過大または過小推定の 傾向があるのかを示す指標であり, RMSE $\left(\hat{\lambda}_{j}\right)$ は $\hat{\lambda}_{j}$ の 推定の誤差の大きさを示す指標である. また $\operatorname{cor}(\hat{\boldsymbol{\lambda}}, \boldsymbol{\lambda})$

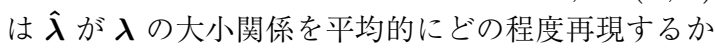
を表す指標である.

なお, 反復回数 $R$ に関しては, 繰り返しごとの項 目母数の推定值の変動を考慮し, 受験者数が 1000 人 の場合には 50 回とし, 受験者数が 300 人の場合には 100 回とした。データの発生アルゴリズムや $\operatorname{Bias}\left(\hat{\lambda}_{j}\right)$, $\operatorname{RMSE}\left(\hat{\lambda}_{j}\right)$ 等の計算アルゴリズムの記述と実行には $\mathrm{R}-$ 2.12 .0 を使用し, 擬似乱数の発生には R-2.12.0に実装 されているメルセンヌッィスターを使用した。

\subsection{MCMC による母数の推定について}

本研究では, MCMCにより母数の推定を行った。具 体的には，各母数の事後分布に打ける期待值を母数の 推定量として採用することとし，MCMCにより得られ た標本の事後平均をもってこれの推定值とした．事後
分布における期待值を解析的に求めるためには多重積 分を解く必要があるが, 今の場合この解を解析的に求 めることは難しい. MCMC を用いることにより，こ のような解析的に求めることの難しい推定値を複雑な 計算を伴うことなく容易に求めることが可能となる.

実際に MCMC を実行し, 各母数の事後平均を事後 分布からの標本により求める際には, WinBUGS 1.4 (Spiegelhalter, Thomas, \& Best, 2003) を使用した. また，MCMCのアルゴリズムとしてはNeal (1997) により提案されたスライスサンプリング法を利用した. 推定にあたっては各母数が互いに独立であると仮定し, 各分析モデルに含まれる母数の事前分布については以 下のように設定した。

-2PLM に含まれる母数の事前分布

$\theta_{i} \quad$ : 標準正規分布 $N(0,1)$

$\alpha_{j}^{* *}:$ 正規分布 $N(1,0.25)$

$\beta_{j}^{* *}:$ 標準正規分布 $N(0,1)$

- BTM に含まれる母数の事前分布

$\theta_{i} \quad$ : 標準正規分布 $N(0,1)$

$\alpha_{j}:$ 正規分布 $N(1,0.25)$

$\beta_{j} \quad$ : 標準正規分布 $N(0,1)$

$\gamma_{i d(j)}:$ 正規分布 $N\left(0, \sigma_{\gamma_{d(j)}}^{2}\right)$

$\sigma_{\gamma_{d(j)}}^{-2}:$ ガンマ分布 $\Gamma(3,1)$

各マルコフ連鎖の初期值については, $\theta_{i}$ に関するもの には 0 と, $\alpha_{j}$ に関するものには 1 と, $\beta_{j}$ に関するもの には 0 と, $\gamma_{i d(j)}$ に関するものには 0 と, $\sigma_{\gamma_{d(j)}}^{-2}$ に関す るものには 3 とした. 各マルコフ連鎖の収束判定には 標本の時系列プロットを使用し, 事前に行ったシミュ レーションの結果から, 全てのシミュレーション条件に おいて, どちらの分析モデルにおいても最初の 1000 個 の標本を burn-in とすることにした．また, MCMCに より事後分布から抽出する標本の数については, WinBUGS User Manual (Spiegelhalter, Thomas, Best, \& Lunn, 2003) に基づき, 各マルコフ連鎖における標 本平均の標準誤差の推定值が, 事後分布からの標本の 標準偏差の約 $5 \%$ 以下になるように設定した。具体的 には，全てのシミュレーション条件に扔いて，2PLM を当てはめた場合には burn-in 後の 3000 個の標本を 母数の推定に用いることとし, BTM を当てはめた場 合には burn-in 後の 4000 個の標本を母数の推定に用 いることとしたななお，WinBUGS を使用する際に用 いた各分析モデルの model file と WinBUGS のプロ グラムコードを記述した Batch file に関しては, 論文 末の Appendix に記載した。 


\section{3. 結}

果

\section{1. 識別力の推定精度に関する結果}

まず，項目反応間の局所依存性が識別力の推定精度 に与える影響に関して, 項目母数の比較可能性を確保 した上で検討を行った。

その結果, $\operatorname{MBias}\left(\hat{\alpha}_{j}^{*}\right)$ の值に関しては, 検討した全て の条件に押いて, 2PLM を当てはめた場合の值が BTM を当てはめた場合の值に比べて $0.031 \sim 0.132$ ほど正の 方向に大きくなった。また, MRMSE $\left(\hat{\alpha}_{j}^{*}\right)$ の值に関 しても，検討した全ての条件に押いて，2PLM を当て はめた場合の值が BTM を当てはめた場合の值よりも 0.026〜0.139 ほど大きくなった。一方, $\operatorname{cor}\left(\hat{\boldsymbol{\alpha}}^{*}, \boldsymbol{\alpha}^{*}\right)$ の值に関しては, $2 \mathrm{PLM}$ を当てはめた場合の值と BTM を当てはめた場合の值との差が-0.311〜0.009 となり， 検討された条件においては，分析モデル間でほとんど 差が見られないか，2PLM を当てはめた場合の值の方 が小さくなっていた。ここでは例として，受験者数が 300 人の場合の分析結果を図 1 3 3 に示す.

\section{2. 困難度の推定精度に関する結果}

つづいて, 項目反応間の局所依存性が困難度の推定 精度に与える影響に関して, 項目母数の比較可能性を 確保した上で検討を行った。

その結果, $\operatorname{MBias}\left(\hat{\beta}_{j}^{*}\right)$ の值に関しては, $2 \mathrm{PLM} を$ 当てはめた場合の值と BTM を当てはめた場合の值と の差が $-0.040 \sim 0.008$ となり，検討された条件におい ては，2つの分析モデル間でほとんど差が見られない か，2PLM を用いた場合の值の方が負の方向にやや大 きくずれていた。また, $M R M S E\left(\hat{\beta}_{j}^{*}\right)$ の值に関しては, 2PLM を当てはめた場合の值と BTM を当てはめた場 合の值との差が $-0.001 \sim 0.054$ となり，検討した全て の条件に扔いて，分析モデル間で差が見られないか， $2 \mathrm{PLM}$ を当てはめた場合の值の方がやや大きくなって いた。一方, $\operatorname{cor}\left(\hat{\boldsymbol{\beta}}^{*}, \boldsymbol{\beta}^{*}\right)$ の值に関しては, 2 PLM を 当てはめた場合の值と BTM を当てはめた場合の值と の差が $-0.006 \sim 0.001$ となっており，検討した全ての 状況に掠いて，両分析モデルともにその推定值が真值 と 0.99 前後の相関を示していた。ここでは例として, 受験者数が 300 人の場合の分析結果を図 $4 \sim 6$ に示す.

\section{3. 項目母数の比較可能性が局所独立性を仮定し た場合の推定結果に与える影響}

1 で述べたように, 先行研究に扔いては本来比較す

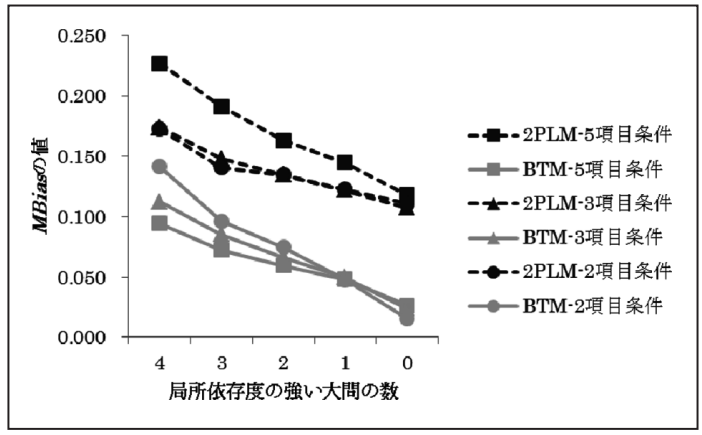

図 1. 受験者数が 300 人の場合の $\operatorname{MBias}\left(\hat{\alpha}_{j}^{*}\right)$ の值

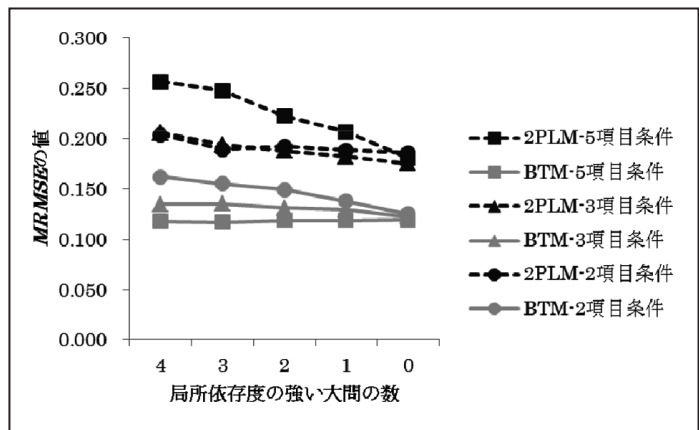

図 2. 受験者数が 300 人の場合の $M R M S E\left(\hat{\alpha}_{j}^{*}\right)$ の值

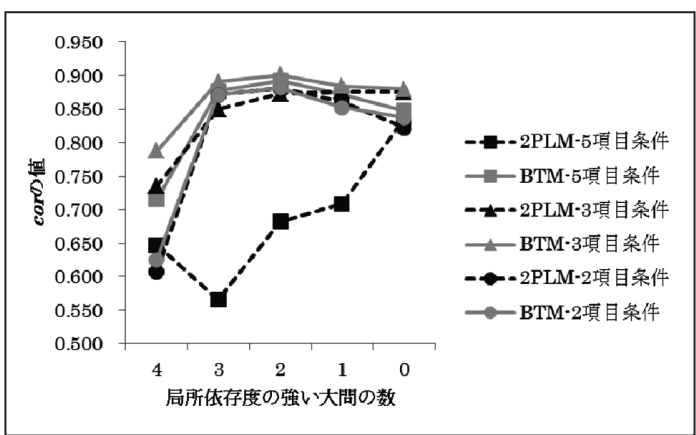

図 3. 受験者数が 300 人の場合の $\operatorname{cor}\left(\hat{\boldsymbol{\alpha}}^{*}, \boldsymbol{\alpha}^{*}\right)$ の値

ることが不可能な項目母数同士が比較され，その結果 に基づき，局所依存性が項目母数の推定に与える影響 について検討がなされてきた。ここでは，項目母数の 比較可能性を確保するか否かによって, 局所独立性を 仮定した場合の推定結果がどのような影響を受けるの かについて，実証的な検討を行うこととする. 


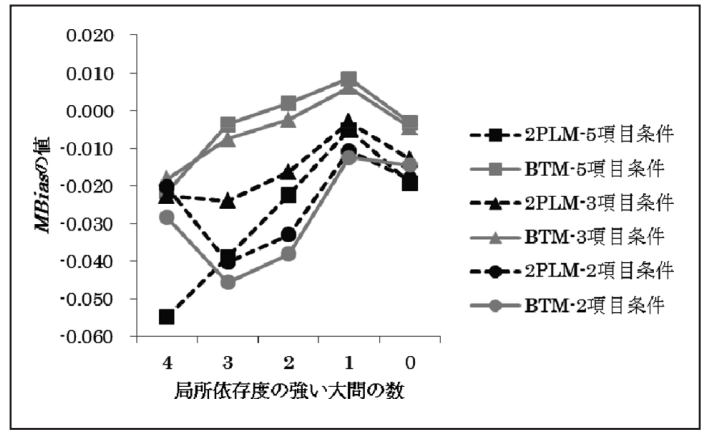

図 4. 受験者数が 300 人の場合の $\operatorname{MBias}\left(\hat{\beta}_{j}^{*}\right)$ の值

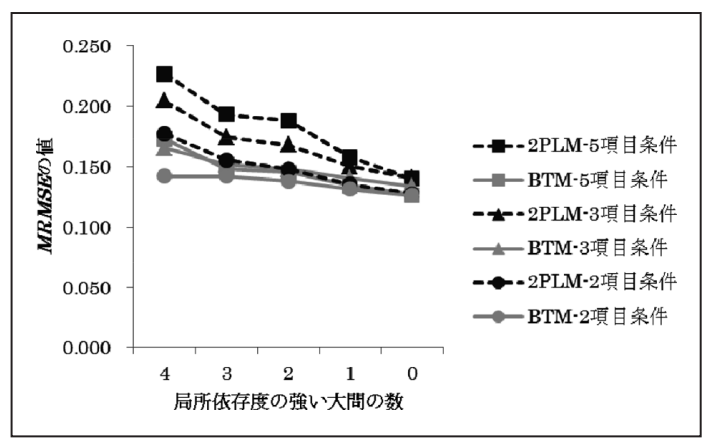

図 5. 受験者数が 300 人の場合の $\operatorname{MRMSE}\left(\hat{\beta}_{j}^{*}\right)$ の值

具体的な手続きとしては, データの発生モデルである 2 值型の BTM に含まれる $\alpha_{j}$ を真の識別力母数とし, 2PLM を分析モデルとした場合に得られる $\alpha_{j}^{* *}$ の推定 值 $\hat{\alpha}_{j}^{* *}$ をその推定值とする，そして，これらの母数なら びに推定值から算出される全 20 項目分のバイアスと平 均二乗誤差平方根のうち局所依存関係にある項目に対 する $\operatorname{Bias}\left(\hat{\alpha}_{j}\right)$ と $R M S E\left(\hat{\alpha}_{j}\right)$ の值を平均し，それぞれ $\operatorname{MBias}\left(\hat{\alpha}_{j}\right), \operatorname{MRMSE}\left(\hat{\alpha}_{j}\right)$ とした. また, 全 20 項目の うち局所依存関係にある項目の $\hat{\alpha}_{j}^{* *}$ と $\alpha_{j}$ の間の相関係 数を算出し, その $R$ 回分の平均を $\operatorname{cor}\left(\hat{\boldsymbol{\alpha}}^{* *}, \boldsymbol{\alpha}\right)$ とした. そして，これらの指標值を，3.1節で $2 \mathrm{PLM}$ を適用し て得られた $\operatorname{MBias}\left(\hat{\alpha}_{j}^{*}\right), \operatorname{MRMSE}\left(\hat{\alpha}_{j}^{*}\right), \operatorname{cor}\left(\hat{\boldsymbol{\alpha}}^{*}, \boldsymbol{\alpha}^{*}\right)$ の值と比較し, 項目母数の比較可能性が局所独立性を 仮定した場合の推定結果に与える影響について検討を 行った。なお， 2.3 節で述べた様に，困難度母数に関し ては， 2 值型の BTM に含まれる $\beta_{j}$ と 2 PLM を分析 モデルとした場合に得られる $\beta_{j}^{* *}$ の推定值 $\hat{\beta}_{j}^{* *}$ との間 で項目母数間の比較可能性が既に確保されているため, 以下困難度母数に関する検討は行わないこととする.

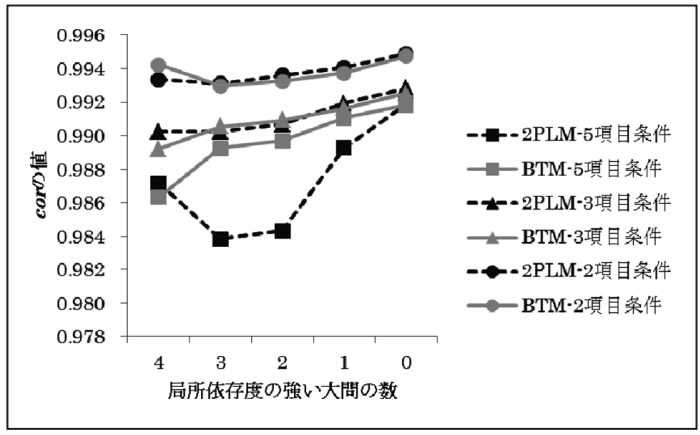

図 6. 受験者数が 300 人の場合の $\operatorname{cor}\left(\hat{\boldsymbol{\beta}}^{*}, \boldsymbol{\beta}^{*}\right)$ の值

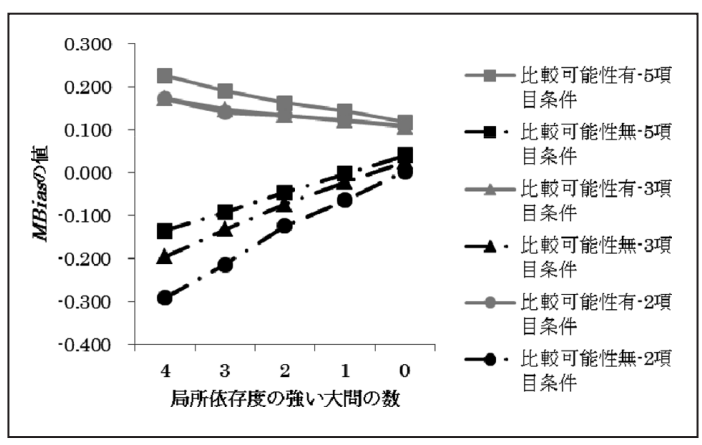

図 7. 受験者数が 300 人の場合のバイアスの值

検討の結果, 項目母数の比較可能性を確保しなかっ た場合，検討された全ての条件において，MBias $\left(\hat{\alpha}_{j}\right)$ の值は $0.077 \sim 0.464$ ほど $\operatorname{MBias}\left(\hat{\alpha}_{j}^{*}\right)$ の值を過少推定 していた.また, $\operatorname{MRMSE}\left(\hat{\alpha}_{j}\right)$ の值と $\operatorname{MRMSE}\left(\hat{\alpha}_{j}^{*}\right)$ の値との差に関しては一貫した傾向は見られなかっ たが，その差の大きさは $0.000 \sim 0.300$ となっており， $\operatorname{MRMSE}\left(\hat{\alpha}_{j}\right)$ の值と $\operatorname{MRMSE}\left(\hat{\alpha}_{j}^{*}\right)$ の值が大きく乘離 する場合も見られた. $\operatorname{cor}\left(\hat{\boldsymbol{\alpha}}^{* *}, \boldsymbol{\alpha}\right)$ の值に関しては, 4 つ の大問全ての局所依存度が強い, または, 弱い場合には, $\operatorname{cor}\left(\hat{\boldsymbol{\alpha}}^{* *}, \boldsymbol{\alpha}\right)$ の值と $\operatorname{cor}\left(\hat{\boldsymbol{\alpha}}^{*}, \boldsymbol{\alpha}^{*}\right)$ の值の差が $-0.058 \sim$ 0.005 となり, 2 つの分析モデル間でほとんど差は見ら れないか, $\operatorname{cor}\left(\hat{\boldsymbol{\alpha}}^{* *}, \boldsymbol{\alpha}\right)$ の值の方がやや小さくなった. それ以外の場合では, 局所依存関係にある項目の数が 5 項目の場合には $\operatorname{cor}\left(\hat{\boldsymbol{\alpha}}^{* *}, \boldsymbol{\alpha}\right)$ の值が $\operatorname{cor}\left(\hat{\boldsymbol{\alpha}}^{*}, \boldsymbol{\alpha}^{*}\right)$ の 值を $0.047 \sim 0.181$ ほど過大推定し, 局所依存関係にあ る項目の数が 3 または 2 である場合には, $\operatorname{cor}\left(\hat{\boldsymbol{\alpha}}^{* *}, \boldsymbol{\alpha}\right)$ の值が $\operatorname{cor}\left(\hat{\boldsymbol{\alpha}}^{*}, \boldsymbol{\alpha}^{*}\right)$ の值を 0.101 0.328 ほど過少推 定する傾向が見られた。ここでは例として，300人の 場合の分析結果を図 7〜9 に示す. 


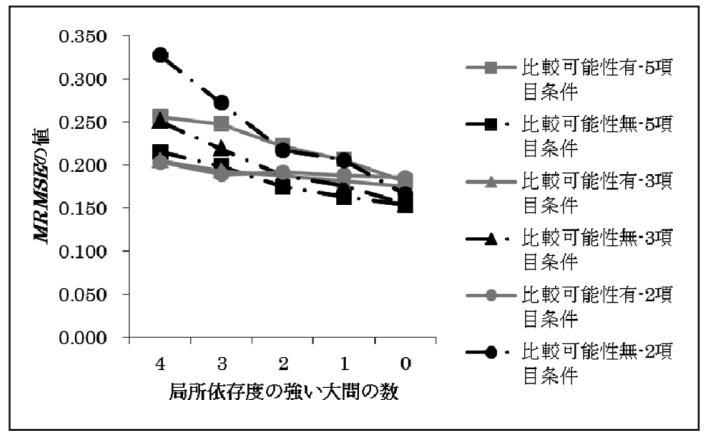

図 8. 受験者数が 300 人の場合の平均二乗誤差平方根の值

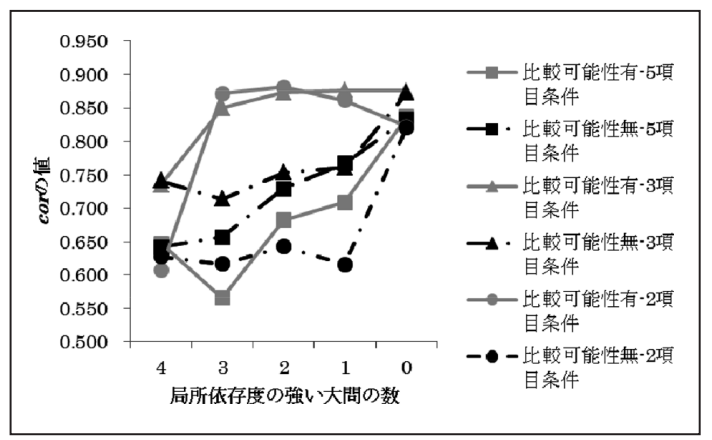

図 9. 受験者数が 300 人の場合の真值と推定值との相関係 数の值

\section{4. 考察}

\section{1. 局所依存性が項目母数の推定に影響を与える メカニズムについて}

本研究では, 項目反応間の局所依存性が項目母数の 推定に与える影響について, 項目母数の比較可能性を 確保した上で検討を行った. その結果, 識別力母数に 関しては, 局所依存性を考慮せずに分析を行った場合, 当該母数が大きく過大推定されてその平均二乗誤差平 方根も大きくなること, 真值と推定值の間の相関係数 に関してはその值が低下する場合もあることが示され た。また，困難度母数に関しては，局所依存性を考慮 せずに分析を行った場合，当該母数が過少推定される 場合もありその平均二乗誤差平方根も大きくなること, ただし，真值と推定值の間の相関係数に関してはほと んど変化が見られないことが示された。

Lord (1980) 等に示されているように, 2PLM に含 まれる $\alpha_{j}^{* *}$ ならびに $\beta_{j}^{* *}$ は, 一定の仮定の下, それぞ れ当該項目 $j$ への項目反応 $u_{j}$ と尺度の和得点 $S$ との
間の双列相関係数 $r_{b_{j}}$ の関数として，それぞれ，

$$
\begin{gathered}
\alpha_{j}^{* *} \cong \frac{r_{b_{j}}}{\sqrt{1-r_{b_{j}}^{2}}} \\
\beta_{j}^{* *} \cong \frac{z_{t_{j}}}{r_{b_{j}}}
\end{gathered}
$$

のように表すことができる。ここで $z_{t_{j}}$ は, $u_{j}$ の背後 に存在すると仮定される潜在変数 $t_{j}$ がその值以上であ れば $u_{j}=1$ となる閾值を表している.データの発生 モデルである 2 值型の BTM には特性值 $\theta$ に加え局所 依存性を表現するための受験者母数 $\gamma$ が含まれており, この $\gamma$ の影響により, 局所依存関係にある項目反応間 の四分相関係数は特性值 $\theta$ のみに基づくものよりも強 いものとなる。したがって, 局所依存性を考慮せずに 分析を行った場合, 局所依存関係にある項目の四分相 関係数は特性值 $\theta$ に基づく相関として過大推定される ことになり, その結果, 当該項目の双列相関係数も過 大推定されることとなる。このとき, 上述の (13) 式は $r_{b_{j}}$ の単調増加関数となり, (14) 式は単調減少関数と なっているので, $2 \mathrm{PLM}$ を当てはめた場合に得られる $\alpha_{j}^{* *}$ ならびに $\beta_{j}^{* *}$ の推定值は, 母数の真值 $\alpha_{j}^{*}$ ならび に $\beta_{j}^{*}$ をそれぞれ過大，過少推定することになる．本 研究で局所独立性を仮定して分析を行った場合に, 局 所依存関係にある項目の識別力と困難度に関するバイ アスが局所依存性を考慮した真のモデルを当てはめた 場合に比べてそれぞれ正と負の方向に大きくなったの は，上記のことが理由であると考えられる。また，局 所依存関係にある項目の識別力と困難度に関する平均 二乗誤差平方根が, 局所独立性を仮定して分析を行っ た場合に共に大きくなったのは, 上述のように, 各母 数のバイアスが大きくなったことがその一因であろう と考えられる。

なお, 識別力母数に関しては, 局所依存性を考慮した 場合にも, 局所独立性を仮定した場合ほどではないに しろ, 真值を過大推定する傾向が見られた. 本シミュ レーションでは $\alpha_{j}$ の事前分布の平均が 1 と, $\sigma_{\gamma_{d(j)}}^{-2}$ の 事前分布の平均が 3 となっていることから, 事前情報 から予測される平均的な $\alpha_{j}^{*}$ の值は 0.949 となる. し たがって， $\alpha_{j}^{*}$ の值が 0.949 よりも小さい項目に関して はその推定值に過大推定の傾向が見られ，0.949より も大きい項目に関しては過少推定の傾向が見られると 考えられる. 実際に各条件における $\alpha_{j}^{*}$ の值を調べて みると, その值は $0.471 \sim 1.257$ となっており,このこ とからは, 局所依存性を考慮した場合にも過大推定さ 
れる傾向にある項目の方が多いことが推察される．局 所依存性を考慮した場合にも識別力母数の真值が過大 推定される傾向にあったのは，上記のことが理由であ ると考えられる。また，(7) 式の分母に $\sigma_{\gamma_{d(j)}}^{2}$ が含ま れていることから, 局所依存度の強い大問に含まれる 項目に関しては, その $\alpha_{j}^{*} か ゙ \alpha_{j}$ よりもより小さくなる 傾向にある。これにより, 局所依存度の強い大問の数 が多いほど，過大推定の傾向が強まったのだと考えら れる. また, 識別力母数と困難度母数ともに, 局所依 存関係にある項目が 5 項目である条件において局所独 立性を仮定した場合にのみ，真値と推定值との相関係 数について他の条件とは異なる挙動が見られた。識別 力母数, 困難度母数ともに, 局所依存関係にある項目 の数が 5 項目である場合には局所依存関係にある項目 の数が 2 や 3 である場合に比べてその推定量のバイア スの絶対值が大きくなる傾向が見られており，この推 定量に生じるバイアスの差が, 上記のような挙動が見 られた一因であると考えられる。

\section{2. 項目母数の比較可能性が項目母数の推定に与 える影響について}

本研究では, 項目母数の比較可能性の有無が局所独 立性を仮定した場合の項目母数の推定に与える影響に 関しても検討を行った。 その結果, 項目母数の比較可 能性を確保せずに局所独立性を仮定した場合の項目母 数の推定精度に関する検討を行った場合, 項目母数の 比較可能性を確保した上で検討を行った場合に比べて, 識別力に関するバイアスが大きく過少推定されること, 平均二乗誤差平方根が過大推定される場合もあること, 局所依存関係にある項目の数が多い場合には真值と推 定值の間の相関係数が過大推定され, それ以外の場合 には過少推定されること等が示された.

これらの結果より, 項目母数の推定に対して局所依 存性が与える影響を検討した先行研究の知見の少なく とも一部は, 項目母数の比較可能性を確保しなかった ために歪められていることが示唆された.

なお, 真值と推定值の間の相関係数に関しては, そ の值が過大推定，あるいは，過少推定され，一貫した 傾向は見られなかった。 4.1 節でも述べたように, 項目 母数の比較可能性を確保した場合，局所依存関係にあ る項目の数が 5 項目である場合には識別力母数の推定 量に生じるバイアスが正の方向に大きくなる。一方で, 項目母数の比較可能性を確保しなかった場合には, 局 所依存関係にある項目の数が減少するにつれてその推
定量にかかるバイアスが負の方向に大きくなっている. そのため, 局所依存関係にある項目が 5 項目である場 合には, 項目母数の比較可能性を確保しなかった場合 に真值と推定值の間の相関係数を過大推定し, 2 項目 あるいは 3 項目である場合には, 過少推定する傾向に あると考えられる。また，4つの大問の局所依存度が 全て等しい場合には, 各項目の推定量に同程度のバイ アスが生じると考えられる。このため, 上記の条件に おいては, 項目母数の比較可能性を確保した場合とし なかった場合との間で真値と推定值との間の相関係数 に差が見られなかったと考えられる。

\section{3. 今後の検討課題}

項目反応間の局所依存性を表現し, かつ, 各項目に 正答する確率が通常の項目反応モデルと等しくなるよ うなモデルも先行研究に抏いていくつか提案されてい る (Braeken, 2011; Braeken et al., 2007; Ip et al., 2009). しかしながら, モデルの単純性や解釈のしやす さ, 引用件数からうかがえる各モデルの普及具合を考 慮し, 今回の研究では, 局所依存性を表現する真の項目 反応モデルとして 2 值型の BTM を使用することとし た.したがって, 今回得られた知見は局所依存性を考 慮せずに分析を行った場合の項目母数の推定精度への 影響を検討したものではあるが, 対象となる項目反応 間の局所依存性が 2 值型の BTM で表現されるもの以 外である場合にも同様の結果が成り立つのかに関して は, 別途検討する必要があると考えられる。 その際使 用され得るモデルとしては, 境界混合モデル (boundary mixture model) (Braeken, 2011) やラッシュ・コ ピュラモデル (Braeken, et al., 2007), 局所依存線形ロ ジスティックテストモデル (locally dependent linear logistic test model) (Ip, et al., 2009) といったモデ ルが挙げられる。

また, 実際のテストデー夕においても本研究で得ら れた知見と同様の傾向が見られるのかどうかに関して は, 項目反応間で局所依存性が生じている実際のテス トデータを利用して別途同様の検討を行う必要がある と考えられる。

\section{謝辞}

東京大学大学院教育学研究科の南風原朝和先生には, 本稿を執筆するにあたり, 大変貴重なご意見, ご指導 を賜りました。心より感謝申し上げます。 
また, 審査員の先生方からも, 本稿に関して貴重な ご意見を賜りました。心より感謝申し上げます。

\section{参 考 文 献}

Bradlow, E.T., Wainer, H., \& Wang, X.H. (1999). A Bayesian random effects model for testlets. Psychometrika, 64, 153-168.

Braeken, J. (2011). A boundary mixture approach to violations of conditional independence. Psychometrika, 76, 57-76.

Braeken, J., Tuerlinckx, F., \& De Boeck, P. (2007). Copula functions for residual dependency. Psychometrika, 72, 393-411.

Chen, C., \& Wang, W. (2007). Effects of ignoring item interaction on item parameter estimation and detection of interacting items. Applied Psychological Measurement, 31, 388-411.

Ferrara, S., Huynh, H., \& Michaels, H. (1999). Contextual explanations of local dependence in item clusters in a large scale hands-on science performance assessment. Journal of Educational Measurement, 36, 119-140.

南風原朝和 (2000). 個人正答確率に基づく局所独立性の 概念の明確化一実験的独立性抢よび一次元性との関 係を中心に一. 2000 年 9 月 26 日 http://www.p.utokyo.ac.jp/ ${ }^{2}$ haebara/local_ind/ (2012 年 5 月 10 日）

Hoskens, M., \& De Boeck, P. (1997). A parametric model for local dependence among test items. Psychological Methods, 2, 261-277.

池田 央 (1992). テストの科学一試験に関わる全ての人に. 日本文化科学社.

Ip, E.H. (2010). Interpretation of the three parameter testlet response model and information function. Applied Psychological Measurement, 34, 467-482.

Ip, E.H., Smith, D.J.M., \& De Boeck, P. (2009). Locally dependent linear logistic test model with person covariates. Applied Psychological Measurement, 33, 555-569.

石塚智一, 中暔菜穂子, 内田照久, 前川黄一 (2001). テ ストレットモデルによる英語試験問題の分析. 大学入 試センター研究紀要, 30, 21-38.

Junker, B.W. (1991). Essential independence and likelihood-based ability estimation for polytomous items. Psychometrika, 56, 255-278.

Kreiner, S. \& Christensen, K.B. (2004). Analysis of local dependence and multidimensionality in graphical loglinear Rasch models. Communications in Statistics - Theory and Methods, 33, 1239-1276.

Lee, G. (2000). A comparison of methods of estimating conditional standard errors of measurement for testlet-based test scores using simulation techniques. Journal of Educational Measurement, 37, 91-112.

Li, Y., Bolt, D.M., \& Fu, J. (2005). A test character- istic curve linking method for the testlet model. Applied Psychological Measurement, 29, 340-356.

Li, Y., Bolt, D.M., \& Fu, J. (2006). A comparison of alternative models for testlets. Applied Psychological Measurement, 30, 3-21.

Lord, F.M. (1980). Applications of item response theory to practical testing problems. Hillsdale, NJ: Erlbaum.

Lord, F.M., \& Novick, M.R. (1968). Statistical theories of mental test scores. Reading, MA: AddisonWesley.

Neal, R. (1997). Markov chain Monte Carlo methods based on 'slicing' the density function. Technical Report 9722, Department of Statistics, University of Tronto, Canada.

Sireci, S.G., Thissen, D., \& Wainer, H. (1991). On the reliability of testlet-based tests. Journal of Educational Measurement, 28, 237-247.

Spiegelhalter, D., Thomas, A., \& Best, N. (2003). WinBUGS 1.4 [Computer program]. Cambridge, UK: MRC Biostatistics Unit, Institute of Public Health.

Spiegelhalter, D., Thomas, A., Best, N., \& Lunn, D. (2003). WinBUGS user manual. Version 1.4. Cambridge, UK: MRC Biostatistics Unit, Institute of Public Health.

登藤直弥 (2010). 局所独立性の仮定が満たされない場合の 潜在特性推定への影響. 日本テスト学会誌, 6, 17-28.

登藤直弥 (2012). 大問形式の問題の項目群への項目反応 に対する確率モデルの比較. 日本テス卜学会誌，8, $85-100$.

Wainer, H, Bradlow, E.T., \& Wang, X.H. (2007). Testlet response theory and its applications. Cambridge University Press.

Yen, W.M. (1993). Scaling performance assessments: Strategies for managing local item dependence. Journal of Educational Measurement, 30, 187213.

(2012 年 5 月 31 日受付, 2012 年 6 月 25 日最終修正)

\section{Appendix}

本研究で使用した model file ならびに Batch fileの コードを以下に記載する。

\section{•2PLM の model file のコード}

\#ただし, P $[i, j] は P_{j}^{* *}\left(\theta_{i}\right), \mathrm{U}[i, j] は u_{j}, \mathrm{t}[\mathrm{j}]$ は $\theta_{i}$, \# $\mathrm{a}[\mathrm{j}]$ は $\alpha_{j}^{* *}, \mathrm{~b}[\mathrm{j}] は \beta_{j}^{* *}$ を, 表すものとする。

model \{

for $(i$ in $1: N)\{$

for $(j$ in $1: J)\{$

$P[i, j]<-1 /(1+\exp (-1.7 * a[j] *(t[i]-b[j])))$

$\mathrm{U}[i, j] \sim \operatorname{dbern}(P[i, j])$ \}

$t[i] \sim \operatorname{dnorm}(0,1)$ 
\}

for $(j$ in $1: \mathrm{J})\{$

$a[j] \sim \operatorname{dnorm}(1,4)$ \}

\}\#model 終了

\section{$\cdot 2$ 值型の BTM の model file のコード}

\#局所依存関係にある項目の数が 5 項目の場合のもの \#を例示する。

\#ただし, $\mathrm{P}[\mathrm{i}, \mathrm{j}]$ は $P_{i}\left(\theta_{i}\right), \mathrm{U}[\mathrm{i}, \mathrm{j}]$ は $u_{j}, \mathrm{t}[\mathrm{i}]$ は $\theta_{i}$, $\# \mathrm{a}[\mathrm{j}]$ は $\alpha_{j}, \mathrm{~b}[\mathrm{j}]$ は $\beta_{j}, \mathrm{~g}[\mathrm{i}, 1]$ は $\gamma_{i d(j)}$ を,

\#tau[1] は $\sigma_{\gamma d(j)}^{-2}$ を, 表すものとする.

model \{

for $(i$ in $1: N)\{$

for $(1$ in $1: 4)\{$

for $(j$ in $(5 * 1-4):(1 * 5))\{$

$P[i, j]<-1 /(1+\exp (-1.7 * a[j] *(t[i]-b[j]-g[i, 1])))$

$U[i, j] \sim \operatorname{dbern}(P[i, j])$ \}

$\mathrm{g}[i, 1] \sim \operatorname{dnorm}(0, \operatorname{tau}[1])$

\}

$t[i] \sim \operatorname{dnorm}(0,1)$

\}

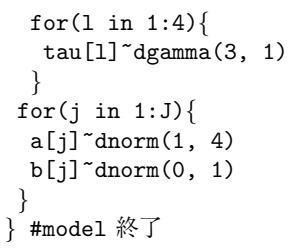

\} \#model 終了

・Batch file のコード

\#分析モデルが 2PLM の場合を例示

display(log) \#output options

check(model file) \#model check

data (data file) \#load data

compile(1) \#compile

inits(1, inits file) \#load inits

update (1000) \#update (burn-in)

set.summary(a) \#summary monitor of a set

set.summary(b) \#summary monitor of $b$ set

set.summary $(t)$ \#summary monitor of $t$ set

update (3000) \#update (sample)

stats.summary $(*)$ \#statistics summary

save (result file) \#save as

\#Batch file 終了 